\title{
Stressed parents, happy parents. An assessment of parenting stress and family quality of life in families with a child with Phelan-McDermid syndrome
}

Gilles Droogmans ${ }^{\text {a }}$, Elfi Vergaelen ${ }^{\text {a, b }}$, Griet Van Buggenhout ${ }^{*, a, c}$, Ann Swillen ${ }^{*, a, c}$

* Joint senior author

a Department of Human Genetics, KU Leuven, Leuven, Belgium

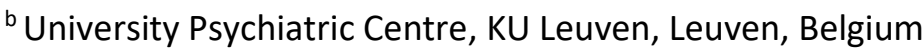

${ }^{c}$ Center for Human Genetics, University Hospitals Leuven (UZ Leuven), Leuven, Belgium

\section{Running title}

Stressed parents, happy parents

\section{Corresponding author}

Gilles Droogmans

gilles.droogmans@kuleuven.be

Department of Human Genetics, KU Leuven

Herestraat 49

BE-3000 Leuven (Belgium)

\section{Acknowledgements}

We would like to thank the patients and their families, the staff and caregivers of the schools and institutions for their kindness, flexibility, and helpful cooperation. We would also like to thank Anneleen Boogaerts (Lab for Constitutional Cytogenetics, UZ Leuven) for her cooperation in designing the supporting materials. Lastly, our thanks go to the members and staff of the Belgian patient association NPO 22q13 for their cooperation and warm interest in the study.

\section{Conflict of interest statement}

The authors have no conflicts of interest to declare. 


\title{
Stressed parents, happy parents. An assessment of parenting stress and family quality of life in families with a child with Phelan-McDermid syndrome
}

\author{
Abstract \\ Background \\ Individuals with Phelan-McDermid syndrome (PMS) are characterised by phenotypical traits that can \\ be experienced as challenging by their environment. This study assessed parenting stress and Family \\ Quality of Life (FQOL) in parents of individuals with PMS and identified potential contributing variables.
}

\section{Method}

Mothers ( $n=14)$ and fathers ( $n=13$ ) of individuals with PMS ( $n=14 ; 6$ females, 8 males; age 2-37, $M=20$, $S D=11.92$ ) completed questionnaires on parenting stress, FQOL, adaptive behaviour and background characteristics.

\section{Results}

Mothers and fathers experienced high, similar and related levels of parenting stress and FQOL satisfaction. Parenting stress and FQOL satisfaction were inversely related. High and low ratings were retrieved for subscales measuring feelings of parental role restriction and emotional wellbeing, respectively. The adaptive skills of the individuals with PMS were related to fathers' parenting stress and FQOL satisfaction.

\section{Conclusions}

Clinical practice is encouraged to be attentive to family dynamics and grasp opportunities to interact with these dynamics.

\section{Keywords}

Phelan-McDermid syndrome, Parenting stress, Family Quality of Life, Adaptive behaviour, Intellectual disability 


\section{Background}

Raising an individual with a disability can be an overwhelming and demanding endeavour. It has been demonstrated that various characteristics at the level of the individual, in addition to other variables as shown, among others, in the ecological model of parenting by Belsky (1984), can be challenging for the parents in particular and for the family as a whole (Hodapp et al., 1992; Maes et al., 2003; Hassall et al., 2005; Lecavalier et al., 2005; Luijkx et al., 2017). Individuals with Phelan-McDermid syndrome (PMS) show several characteristics that are described by parents, caregivers and researchers as demanding and challenging. PMS is a rare congenital condition. Its prevalence is unknown, but worldwide at least 2000 cases are reported (Phelan-McDermid Syndrome Foundation, 2019). PMS is caused by a heterozygous deletion at chromosome 22q13.3 involving the SHANK3 gene or a pathogenic variant in the gene (Bonaglia et al. 2001; Bonaglia et al., 2006; Durand et al., 2007; Bonaglia et al., 2011; Soorya et al, 2013; Sarasua et al, 2014). Despite a high phenotypic variability (Phelan \& McDermid, 2012; Droogmans et al., 2019), several core characteristics can be distinguished: intellectual disability, delayed to absent speech and features of autism spectrum disorder (ASD) (Phelan et al., 2001; Havens et al., 2004; Manning et al., 2004; Cusmano-Ozog et al., 2007; Dhar et al., 2010; Shaw et al., 2011; Phelan \& McDermid, 2012; Soorya et al., 2013; Zwanenburg et al., 2016). In addition to these characteristics, various medical conditions, such as seizures, lymphedema or renal problems, are observed (Phelan \& McDermid 2012; Kolevzon et al. 2014). Furthermore, there is a high incidence of challenging behaviour and psychiatric disorders such as attention deficit and hyperactivity disorder (ADHD) and bipolar disorder (BPD) (Shaw et al., 2011; Denayer et al. 2012; Droogmans et al. 2019). Sometimes subsequent to acute medical events, such as catatonic phase, epileptic state or malignant neuroleptic syndrome, regression is noticed (Bonaglia et al. 2011; Denayer et al. 2012; Serret et al. 2015; Soorya et al. 2013; Egger et al., 2016). Reierson et al. (2017) reported a regression in motor and self-help skills which is likely to be apparent from mid-childhood. Droogmans et al. (2019) reported parents and caregivers noticing a decline in several domains: language (use of words), fine and gross motor function, adaptive behaviour, activity and sensory tolerance.

The parental role, regardless of the specific needs of the child, is inextricably linked to parental obligations and demands. The responsibilities ensuing from the parental role can lead to 'parenting stress'. This is an aversive psychological reaction that parents have towards themselves and towards the child, especially when the parenting demands are not consistent with one's parental expectations and/or one's personal or social resources (Deater-Deckard, 1998; Holly et al., 2019). Theories and studies on parenting stress underline the reciprocity with issues in child adjustment: raising children with emotional or behavioural issues increases parenting stress, and parents who experience higher levels of parenting stress are likely to use less efficient parenting strategies, which might maintain or 
worsen the emotional or behavioural issues of the child (Quine \& Pahl, 1991; Abidin, 1992; Baker et al., 2003; Deater-Deckard, 2004; Hassall et al., 2005; Lecavalier et al., 2005; Holly et al., 2019). Besides child adjustment, parenting stress is demonstrated to be associated with several other outcomes, such as parent mental health and well-being, and family functioning (Holly et al., 2019). The role of parent gender in parenting stress has been studied extensively among a variety of populations and is subject to mixed results (Deater-Deckard \& Scarr, 1996). Herring et al. (2006), Oelofsen and Richardson (2006) and Shin et al. (2006) found mothers of children with intellectual disabilities to report higher levels of parenting stress. However, McCarthey et al. (2006) and Mitchell, Szczerepa and Hauser-Cram (2016) reported mothers and fathers of children or adolescents with intellectual disabilities to experience similar levels of parenting stress. Research in clinical populations furthermore demonstrated that mothers of children with Down syndrome, in comparison to mothers of typically developing children, have significantly higher levels of parenting stress on the Short Form of the Parenting Stress Index (PSISF; Abidin, 1995) (Phillips et al., 2017). Similarly, mothers of children with Fragile X syndrome had higher levels of parenting stress in contrast to the mean normative scores as was measured by the Parenting Stress Index (PSI; Abidin, 1995) (Johnston et al., 2003).

Determining the level of parenting stress is one of several conceptualizations used by professionals and researchers to grasp the impact of having a child with a disability on the family (Wang et al., 2004). However, it is a negative measure as its focus is on the negative concept of stress (Gardiner \& larocci, 2012). Another - more positive - approach is the assessment of the satisfaction of family members with the family life. Within the family there is, as is defined by Zuna et al. (2010), a 'dynamic sense of wellbeing, collectively and subjectively defined and informed by its members, in which individual and family-level needs interact'. This theoretical framework is called 'Family Quality of Life' (FQOL). FQOL highlights the fulfilment of the family's needs, the enjoyment of family life, and whether the family members have the opportunity to do the things that are important to them (Beach Center on Disability, 2003; Park et al., 2003, Vanderkerken et al., 2018). Research on Flemish families with a child with intellectual disabilities reported relatively high satisfaction ratings (Steel et al., 2011; Vanderkerken et al., 2018). Wang et al. (2004) found severity of the disability (e.g. motor, vision, hearing, intellectual or psychiatric problems) to be an important predictor in both mothers' and fathers' ratings on the Beach Center Family Quality of Life Scale (FQOL Scale; Hoffman et al., 2006). Vanderkerken et al. (2018) reported respondent age, employment situation and support needs of the child to explain differences in the respondents' ratings. Wang et al. (2004) reported fathers to rate FQOL slightly higher than mothers, whereas the studies by Wang et al. (2006) and Vanderkerken et al. (2018) did not find a difference in FQOL satisfaction ratings with regard to parent gender. 
The construct of parenting stress has been well studied in several populations with different needs. The framework of FQOL is relatively new, especially in contrast to parenting stress, but is growing in interest by researchers worldwide. However, to the best of our knowledge, both parenting stress and FQOL have not yet been explored in families with a child with PMS. The aim of the present study was to assess parenting stress and FQOL in parents of persons with PMS, to explore differences between mother and father ratings, to study the link between parenting stress and FQOL and to identify potential contributing variables in the context of parenting stress and FQOL.

\section{Method}

\section{Participants and procedure}

The research protocol was approved by the Ethics Committee of X. All individuals with a confirmed genetic diagnosis of PMS known to the Center for Human Genetics (University Hospitals Leuven, Belgium) ( $\mathrm{N}=21$ ) were invited by their clinical geneticist to participate in the study. Whether or not they participated in the study did not in any way influence their future care. As an inclusion criterion, individuals needed to have active contact with their family. If interested, an appointment was made for a home visit. The visits took place between April and July 2019 and were jointly done by two researchers, a clinical educational psychologist (first author) and a psychiatrist (second author). The first and second author were not involved in the participants' care. During the visit the study was explained, informed consent was obtained, and the bundle of questionnaires was discussed with the participants. After the visit, the participants were given ample time to complete and return the questionnaires.

\section{Instruments}

\section{Parenting stress}

A set of questionnaires was composed. For the screening of parenting stress the Dutch adaptation of the PSI-SF was chosen (NOSIK; De Brock et al., 1992). The questionnaire consists of 25 items, divided into a parent (11 items) and child domain (14 items). A parent of a child between 2 and 13 years old scores the 25 items according to a 6-point Likert scale, ranging from 1 (total disagreement) to 6 (total agreement). The Dutch version of the PSI-SF is a respected and widely used instrument, but is advised to be no longer used because of outdated norms (COTAN, 1996). Therefore we have included a second, more recent measure to screen for parenting stress: the Parenting stress questionnaire by Vermulst, Kroes, De Meyer, Nguyen and Veerman (2015) (translated 'Opvoedingsbelastingsvragenlijst', OBVL). The OBVL consists of 34 items, divided into five subscales. All subscales relate to the parent domain only. The subscale 'Problems with the Parent-Child Relationship' refers to the extent to which the parent experiences the relationship between parent and child as stressful and problematic (6 items). The subscale 'Parenting Problems' refers to the extent to which the parent perceives raising the child 
as a burden and feels she or he lacks the skills to have adequate control over the child ( 7 items). The subscale 'Depressive moods' refers to the extent to which a parent is (un)happy with oneself and one's living conditions (7 items). The subscale 'Role Restriction' refers to the extent to which the parental role is experienced as a restriction of one's own freedom and as a frustration as a result of repeated attempts to maintain one's own identity (6 items). The last subscale 'Health issues' examines to what extent the parent feels healthy ( 8 items). A parent of a child between 0 and 18 years old scores the 34 items according to a 4-point Likert scale, ranging from 1 (does not apply) to 4 (does certainly apply). By converting the rough scores to T-scores using the norm tables, an interpretation can be obtained of the severity: no significant problems, mild problems, serious problems. Psychometric research by the authors of the OBVL shows good results for reliability and validity (Vermulst et al., 2015).

\section{Family Quality of Life}

FQOL was measured by the FQOL Scale (Hoffman et al., 2006), translated to Dutch by Vanderkerken et al. (2018). The questionnaire consists of 25 items, addressing the five FQOL domains: family interaction (6 items), parenting (6 items), emotional wellbeing ( 4 items), physical/material wellbeing ( 5 items), and disability-related support ( 4 items). The participating family member scores the items according to a 5-point Likert scale, ranging from 1 (very dissatisfied) to 5 (very satisfied). Furthermore, the participant was given the possibility to elaborate in one or two sentences on the rationale of the satisfaction rating, as was suggested by Vanderkerken et al. (2018). Extensive psychometric research on the FQOL Scale showed satisfactory results (for detailed information, see Wang et al., 2004; Beach Center On Disability, 2005; Summers et al., 2005; Hoffman et al., 2006; Wang et al. 2006). Unfortunately, the Dutch translation of the FQOL Scale has not yet been validated for the Flemish population.

\section{Adaptive behaviour}

Harrison and Oakland (2015) developed the Adaptive Behavior Assessment System - Third Edition (ABAS-3) to assess the adaptive skills of individuals between 0 and 89 years old. For the present study, the Dutch adaptation of the ABAS-3 for children between 0 and 5 years old was used (ABAS-3-NL; Kreemers et al., 2019) as this version is the most appropriate considering the developmental level of the participants. Adaptive behaviour refers to the effectiveness and the extent to which a person meets the requirements of personal independence and social responsibility, in accordance with her or his age and culture (Schalock, 2004; Schalock \& Luckasson, 2004). Various skills are distinguished. For the age group 0-5 years a distinction is made between three adaptive domains: conceptual, social and practical which cover nine adaptive skill areas: communication (26 items), functional pre-academics (24 items) and self-direction (24 items); leisure (24 items) and social (24 items); and self-care (24 items), community use (22 items), home living ( 25 items), and health and safety ( 22 items). A tenth 
skill area, motor skills (26 items), does not belong to any of the three domains, but is included in the total score. The questionnaire consists of a total of 241 items. The parent scores the items according to a 4-point Likert scale, ranging from 0 (the individual is unable to exhibit the intended behaviour) to 3 (the individual is able to exhibit the intended behaviour and always (or almost always) exhibits the intended behaviour when needed). Furthermore, the parent is asked to indicate whether the answer given is an estimation. The reliability and validity study by Kreemers et al. (2019) showed, based on raw data, excellent preliminary results.

\section{Background data}

A general background questionnaire was composed to yield data on family composition, amount of days per week spent within the family, employment rate and (professional and social) support. A translated version of the questionnaire can be found in Appendix.

\section{Statistical methods}

Statistical analyses were performed on the raw data of the PSI-SF, FQOL Scale and ABAS. The raw scores of the FQOL Scale were transformed to average satisfaction ratings. T-scores were used for the OBVL. The data were analysed with JASP (JASP Team, 2019). Due to violations of the assumptions, only non-parametric methods were used: Kendall's Tau-b was calculated for correlation analyses, Wilcoxon's signed rank test was conducted to compare two related samples, and Mann-Whitney U or Kruskal-Wallis test was performed to test for differences between two or two or more groups, respectively. The null-hypothesis was rejected when a p-value less than 0.05 (two-tailed exact significance level) was reached.

There were missing values in the data set as for one participant the father did not participate in the study. Data from this participant were excluded pairwise, resulting in the loss of one participant when data on fathers were analysed.

\section{Results}

Of the 21 individuals with PMS known at the Center for Human Genetics 16 participated, reaching a response rate of 76.19\%. Two participants were excluded from the study. One individual was excluded since he no longer had ties with his family (Rilotta et al., 2011). Another individual was excluded because the questionnaires were filled out by the grandparents instead of the parents, therefore compromising the comparability of the data. Altogether, data of 14 individuals were included in the study (14 mothers and 13 fathers). Table 1 gives an overview of the characteristics of the included individuals and their families. Figure 1 and Table 2 give an overview of the individuals' genetic characteristics, in particular with respect to the terminal end of chromosome 22. 


\section{Table 1}

Characteristics of the individual with PMS and her or his family

Individual with Number of individuals included

PMS

\section{Age (years)}

Gender

Number of nights per week spent within the family

Family

\author{
Mothers Number \\ Age \\ Employment rate \\ Fathers Number \\ Age \\ Employment rate
}

Marital status of the family

Number of siblings $\mathrm{n}=14$

\begin{tabular}{|c|c|c|}
\hline$M=20$ & $S D=11.928$ & Range: 2 - 37 \\
\hline Female & & $n=6$ \\
\hline Male & & $\mathrm{n}=8$ \\
\hline$\leq 2$ nights & & $\mathrm{n}=5$ \\
\hline$\geq 3$ nights & & $n=9$ \\
\hline
\end{tabular}

$\mathrm{n}=14$

$M=48.857 \quad S D=11.825 \quad$ Range: $31-66$

Full-time employment $\quad \mathrm{n}=3$

Part-time employment $\quad \mathrm{n}=3$

No employment $\quad n=8$

$\mathrm{n}=13$

$M=50.615 \quad S D=13.301 \quad$ Range: $27-68$

Full-time employment $\quad \mathrm{n}=11$

Part-time employment $\quad \mathrm{n}=0$

No employment $\quad n=2$

Divorced $\quad \mathrm{n}=1$

Married $n=13$

no siblings $\quad n=6$

1 sibling $\quad \mathrm{n}=3$

2 siblings $n=3$

3 siblings $\quad n=1$

7 siblings $\quad n=1$ 
Use of support

provided by the family's network (e.g. babysitting or housekeeping by a

Support

$\mathrm{n}=5$

grandparent

provided by generally accessible services (e.g. housekeeping services)

No support

$\mathrm{n}=9$

Support

$\mathrm{n}=6$

provided by services for people with disabilities (e.g. special education or daycare

No support

$\mathrm{n}=8$ centre)

Support

$\mathrm{n}=14$

No support

$\mathrm{n}=0$

Note $\mathrm{n}=$ sample size; $M=$ mean; $S D=$ Standard Deviation; $\leq=$ less than or equal to; $\geq$ = greater than or equal to 


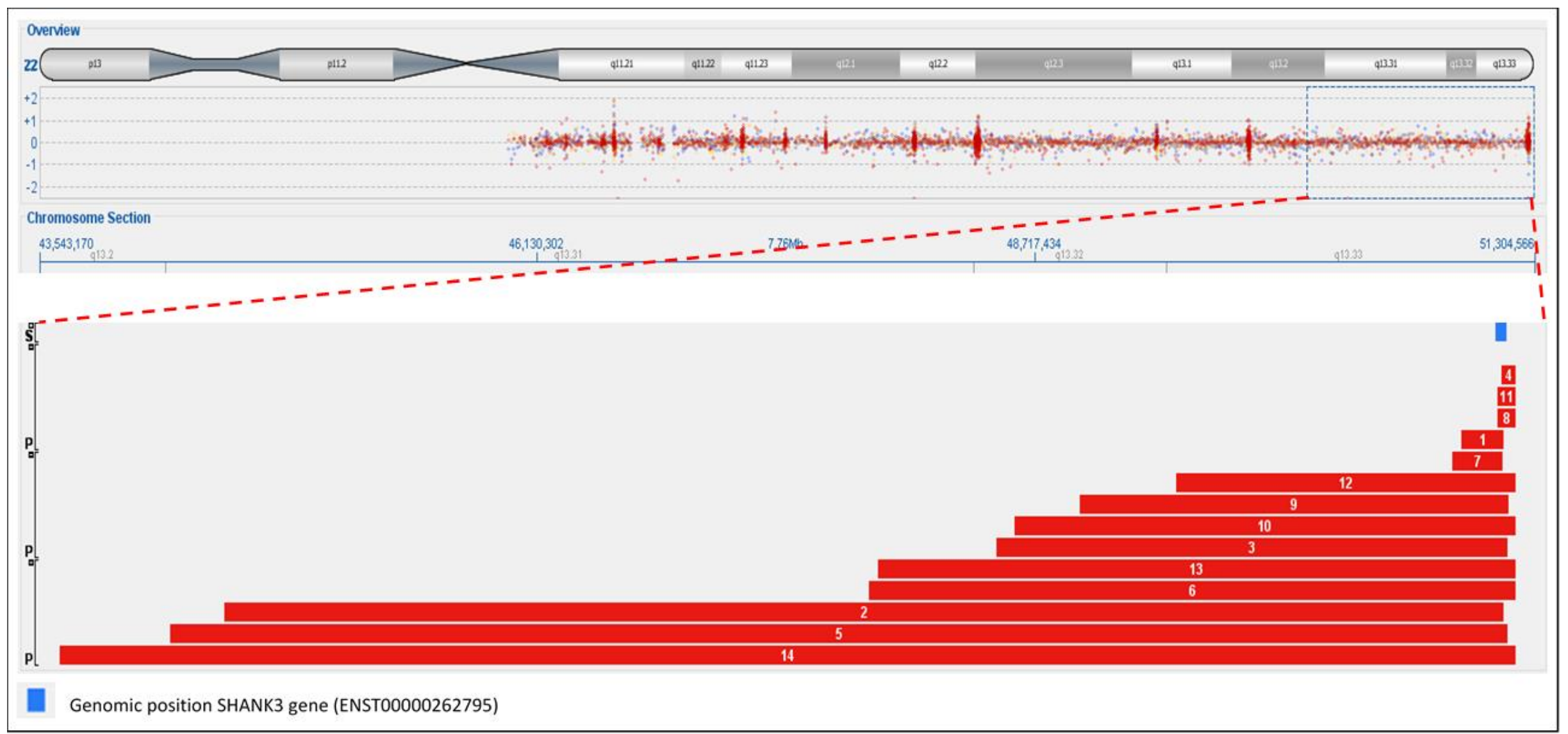

Figure 1 Deletion sizes on the terminal end of chromosome 22 
Table 2

Deletion sizes with respect to the terminal end of chromosome 22

\begin{tabular}{lcll}
\hline SHANK 3 & size $(\mathrm{kb})$ & start & stop \\
\hline $\begin{array}{l}\text { Genomic } \\
\text { position of }\end{array}$ & & & \\
SHANK 3 & 58.6 & 51113070 & 51171641
\end{tabular}

\begin{tabular}{llll}
\hline Individual & deletion size $(\mathrm{kb})$ & start & stop \\
\hline P1 & 217.4 & 50937280 & 51154705 \\
P2 & 6652.2 & 44505539 & 51157780 \\
P3 & 2661.1 & 48517389 & 51178515 \\
P4 & 75.7 & 51145237 & 51220923 \\
P5 & 6954.7 & 44223471 & 51178205 \\
P6 & 3432.7 & 47859481 & 51220923 \\
P7 & 259.1 & 50890078 & 51149209 \\
P8 & 97.4 & 51123497 & 51220923 \\
P9 & 2232.6 & 48950813 & 51183428 \\
P10* & 2605.3 & 48615664 & 51220923 \\
P11 & 97.4 & 51123497 & 51220923 \\
P12 & 1764.6 & 49456297 & 51220923 \\
P13 & 3315.6 & 47905322 & 51220923 \\
P14* & 7572.8 & 43648087 & 51220923 \\
\hline
\end{tabular}

Note Patients with * have ring chromosome 22 (de novo).

Note In some patients additional mutations were found: P1 DupXp22.33 (226 kb, maternally inherited); P3 Dup3q26.1 (826kb, paternally inherited); P7 Del17q11.2 (62kb, Exon 2 and 3 of NF1 deleted, de novo); P9 Dup9q21.32q21.33 (22Mb, maternally inherited); P13 Dup1q42.2-q44 (15Mb; De novo) and DelXq27.3 (maternally inherited) 


\section{A descriptive approach to parenting stress and FQOL}

The means, standard deviations and five-number summary (minimum, first quartile, median, third quartile and maximum; Hoaglin et al. 1983) were determined for the PSI-SF, OBVL, and FQOL Scale. The mean and median parenting stress scores of mothers and fathers on the PSI-SF were in comparison to the norm group high and very high, respectively (Table 3). The lowest PSI-SF rating was, when compared to the norm group, below average for mothers and average for fathers. Standard deviations were large.

\begin{tabular}{|c|c|c|}
\hline \multicolumn{3}{|c|}{$\begin{array}{l}\text { Table } 3 \\
\text { Distribution of PSI-SF ratings }\end{array}$} \\
\hline & $\begin{array}{l}\text { PSI-SF mother } \\
(\mathrm{n}=14)\end{array}$ & $\begin{array}{l}\text { PSI-SF father } \\
(n=13)\end{array}$ \\
\hline$M$ & 83.857 & 79.154 \\
\hline$S D$ & 22.833 & 20.808 \\
\hline Min & 41.000 & 45.000 \\
\hline Q1 & 67.750 & 67.000 \\
\hline$M d n$ & 86.500 & 82.000 \\
\hline Q3 & 101.750 & 88.000 \\
\hline Max & 112.000 & 118.000 \\
\hline \multicolumn{3}{|c|}{$\begin{array}{l}\text { Note } \mathrm{n}=\text { sample size; } M=\text { mean; } S D= \\
\text { Standard Deviation; Min = Minimum; } Q 1= \\
\text { first quartile; Mdn = Median; } Q 3=\text { third } \\
\text { quartile; Max = Maximum }\end{array}$} \\
\hline
\end{tabular}

Scores on the OBVL questionnaire were high (Table 4, Figure 2). On average and when compared to the norm group, both mothers and fathers experienced 'serious problems' with overall parenting stress and with respect to the subscale Role Restriction. When examining the median scores, mothers scored above the 'Serious problems' cut-off for the total questionnaire $(>64)$ and the subscale Role Restriction (>69). Fathers scored above the 'Serious problems' cut-off for the total questionnaire (>64) and above the 'Mild problems' cut-off for all subscales except the subscale Health Issues (>65). With respect to the subscale Role Restriction fathers scored above the cut-off for 'Serious problems' (>69). The lowest scores were, when compared to the norm group, below the 'Mild problems' cut-off for mothers and fathers. 


\begin{tabular}{|c|c|c|c|c|c|c|c|}
\hline \multicolumn{8}{|c|}{$\begin{array}{l}\text { Table } 4 \\
\text { Distribution of OBVL T-scores }\end{array}$} \\
\hline & & Total & $\begin{array}{l}\text { Problems with } \\
\text { Parent-Child } \\
\text { Relationship }\end{array}$ & $\begin{array}{l}\text { Parenting } \\
\text { Problems }\end{array}$ & $\begin{array}{l}\text { Depressive } \\
\text { Moods }\end{array}$ & $\begin{array}{c}\text { Role } \\
\text { Restriction }\end{array}$ & $\begin{array}{l}\text { Health } \\
\text { Issues }\end{array}$ \\
\hline \multirow{7}{*}{$\begin{array}{l}\text { Mother } \\
(n=14)\end{array}$} & $M$ & 65.071 & 59.571 & 60.286 & 58.857 & 67.786 & 64.643 \\
\hline & $S D$ & 10.336 & 9.053 & 11.418 & 9.469 & 10.700 & 8.906 \\
\hline & Min & 45.000 & 45.000 & 40.000 & 45.000 & 49.000 & 49.000 \\
\hline & Q1 & 56.000 & 53.750 & 51.000 & 49.750 & 58.500 & 62.000 \\
\hline & Mdn & 68.500 & 57.000 & 61.500 & 61.500 & 72.500 & 64.500 \\
\hline & Q3 & 71.750 & 66.500 & 70.000 & 66.500 & 76.000 & 70.500 \\
\hline & Max & 78.000 & 74.000 & 76.000 & 74.000 & 79.000 & 80.000 \\
\hline \multirow{7}{*}{$\begin{array}{l}\text { Father } \\
(n=13)\end{array}$} & $M$ & 69.000 & 63.846 & 63.308 & 63.769 & 69.385 & 62.462 \\
\hline & $S D$ & 8.573 & 9.227 & 10.363 & 10.521 & 12.238 & 8.202 \\
\hline & Min & 51.000 & 45.000 & 35.000 & 45.000 & 48.000 & 49.000 \\
\hline & Q1 & 63.000 & 58.000 & 63.000 & 60.000 & 60.000 & 58.000 \\
\hline & Mdn & 71.000 & 68.000 & 67.000 & 65.000 & 77.000 & 62.000 \\
\hline & Q3 & 76.000 & 69.000 & 67.000 & 71.000 & 79.000 & 68.000 \\
\hline & Max & 78.000 & 80.000 & 77.000 & 77.000 & 80.000 & 77.000 \\
\hline
\end{tabular}

Note $\mathrm{n}=$ sample size; $M=$ mean; $S D=$ Standard Deviation; $M i n=$ Minimum; $Q 1$ = first quartile; $M d n$ = Median; $Q 3$ = third quartile; Max = Maximum

Note 'Mild problems' cut-off is 60 for the total questionnaire and 65 for the subscales; 'Serious problems' cut-off is 64 for the total questionnaire and 69 for the subscales. 


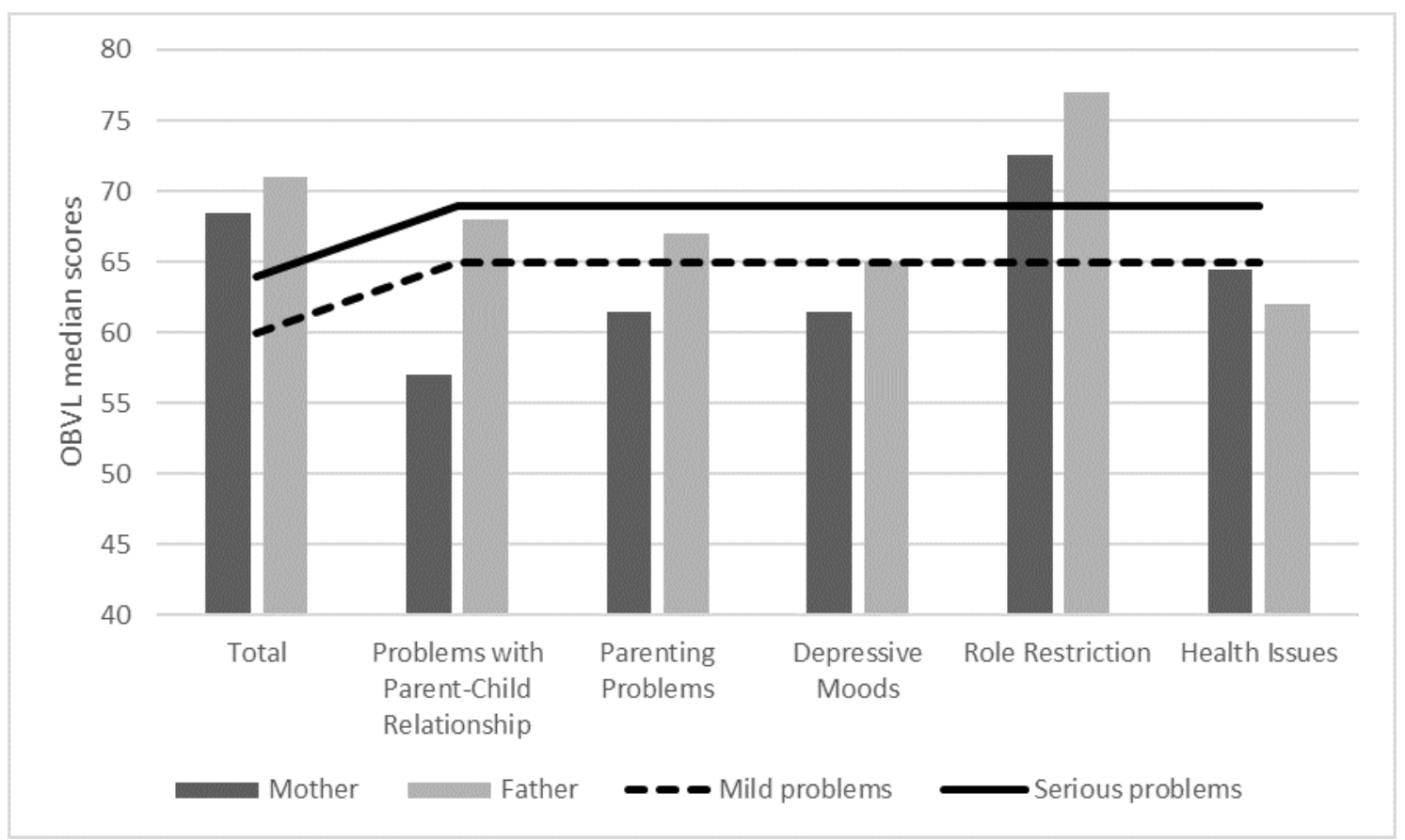

Figure 2 OBVL median scores compared to norm cut-off

Note 'Mild problems' cut-off is 60 for the total questionnaire and 65 for the subscales; 'Serious problems' cut-off is 64 for the total questionnaire and 69 for the subscales.

Total FQOL satisfaction was high (Table 5). On average both mothers and fathers were satisfied. Fathers were, on average and when compared to mothers, a little less satisfied with the disability related support. Emotional wellbeing was rated the lowest by mothers and fathers, but was still within the upper range of the 5-point Likert scale. Standard deviations were small, but were slightly larger for fathers (except for the subscale Disability related support). Analyses on the rationale of the satisfaction rating (Vanderkerken et al., 2018) could not be performed as for only two parents qualitative comments were received. 
Table 5

Distribution of average FQOL Scale satisfaction ratings

\begin{tabular}{|c|c|c|c|c|c|c|c|}
\hline & & Total & $\begin{array}{l}\text { Family } \\
\text { Interaction }\end{array}$ & Parenting & $\begin{array}{l}\text { Emotional } \\
\text { Wellbeing }\end{array}$ & $\begin{array}{l}\text { Physical/m } \\
\text { aterial } \\
\text { Wellbeing }\end{array}$ & $\begin{array}{l}\text { Disability- } \\
\text { related } \\
\text { support }\end{array}$ \\
\hline \multirow[t]{7}{*}{ Mother $(n=14)$} & $M$ & 4.054 & 4.143 & 3.952 & 3.607 & 4.329 & 4.036 \\
\hline & $S D$ & 0.273 & 0.380 & 0.441 & 0.516 & 0.320 & 0.458 \\
\hline & Min & 3.760 & 3.667 & 3.000 & 2.750 & 4.000 & 3.500 \\
\hline & Q1 & 3.880 & 3.875 & 3.833 & 3.313 & 4.050 & 3.563 \\
\hline & $M d n$ & 4.000 & 4.000 & 3.917 & 3.500 & 4.200 & 4.125 \\
\hline & Q3 & 4.120 & 4.292 & 4.125 & 3.750 & 4.550 & 4.250 \\
\hline & Max & 4.760 & 5.000 & 5.000 & 5.000 & 5.000 & 4.750 \\
\hline \multirow[t]{7}{*}{ Father $(n=13)$} & $M$ & 4.015 & 4.038 & 4.013 & 3.712 & 4.338 & 3.808 \\
\hline & $S D$ & 0.391 & 0.472 & 0.529 & 0.636 & 0.435 & 0.435 \\
\hline & Min & 3.480 & 3.500 & 3.000 & 2.750 & 3.600 & 3.000 \\
\hline & Q1 & 3.760 & 3.667 & 3.667 & 3.500 & 4.000 & 3.750 \\
\hline & $M d n$ & 3.920 & 4.000 & 4.000 & 3.500 & 4.200 & 3.750 \\
\hline & Q3 & 4.160 & 4.167 & 4.167 & 4.250 & 4.600 & 4.000 \\
\hline & $\operatorname{Max}$ & 4.840 & 5.000 & 5.000 & 4.750 & 5.000 & 4.750 \\
\hline
\end{tabular}

Note $\mathrm{n}=$ sample size; $M=$ mean; $S D=$ Standard Deviation; $M i n=$ Minimum; $Q 1$ = first quartile; $M d n$

= Median; $Q 3$ = third quartile; $\operatorname{Max}=$ Maximum

Note 1 (very dissatisfied); 2 (dissatisfied); 3 (neither dissatisfied, nor satisfied); 4 (satisfied); 5 (very satisfied)

\section{Parenting stress and FQOL satisfaction by mothers and fathers compared}

As Table 3, 4 and 5 illustrate, mothers and fathers differed only slightly in their PSI-SF, OBVL and FQOL satisfaction ratings. Correlational analyses (Table 6 and 7) showed mother and father ratings to be significantly related to each other for the PSI-SF ( $\tau b=0.494, p=0.020)$ and the OBVL ( $\tau b=0.474, p=0.027$; Table 6). Furthermore several OBVL subscales were significantly related (e.g. Parenting problems, $\tau b=0.681, p=0.002$; Table 6). For total FQOL satisfaction, mother and father ratings were only marginally related to each other ( $\tau b=0.411, p=0.05 ;$ Table 7$)$. However, on a subscale level, significant correlations were found for the Parenting subscale $(\tau b=0.766, p<0.001)$ and other subscales (Table 7$)$. A Wilcoxon signed rank test showed no statistically significant differences $(p>0.05)$ between mother and father ratings for the PSI-SF, OBVL and FQOL scale and their respective subscales. 


\section{Table 6}

Correlations between mother and father OBVL ratings

\begin{tabular}{|c|c|c|c|c|c|c|c|c|}
\hline & & & & & Mother ( $r$ & $n=14)$ & & \\
\hline & & & Total & $\begin{array}{c}\text { Problems with } \\
\text { Parent-Child } \\
\text { Relationship }\end{array}$ & $\begin{array}{l}\text { Parenting } \\
\text { Problems }\end{array}$ & $\begin{array}{c}\text { Depressive } \\
\text { Moods }\end{array}$ & $\begin{array}{c}\text { Role } \\
\text { Limitation }\end{array}$ & $\begin{array}{l}\text { Health } \\
\text { Issues }\end{array}$ \\
\hline $\begin{array}{l}\text { Father } \\
(n=\end{array}$ & Total & $\begin{array}{l}\text { Kendall's } \\
\text { tau B }\end{array}$ & $\begin{array}{c}0.47 \\
4\end{array}$ & 0.405 & 0.384 & 0.384 & $0.497 *$ & 0.133 \\
\hline & TOldl & $\mathrm{p}$-value & $\begin{array}{r}0.02 \\
7\end{array}$ & 0.063 & 0.074 & 0.074 & 0.022 & 0.537 \\
\hline & Problems with & $\begin{array}{l}\text { Kendall's } \\
\text { tau B }\end{array}$ & $\begin{array}{r}0.34 \\
7\end{array}$ & $0.466 *$ & 0.416 & 0.228 & 0.367 & 0.000 \\
\hline & Relationship & $p$-value & $\begin{array}{r}0.10 \\
8\end{array}$ & 0.034 & 0.055 & 0.293 & 0.093 & 1.000 \\
\hline & Parenting & $\begin{array}{l}\text { Kendall's } \\
\text { tau B }\end{array}$ & $\begin{array}{c}0.48 \text { * } \\
7\end{array}$ & 0.306 & $0.681 * *$ & -0.041 & 0.317 & 0.343 \\
\hline & Problems & $p$-value & $\begin{array}{r}0.02 \\
5\end{array}$ & 0.167 & 0.002 & 0.852 & 0.150 & 0.118 \\
\hline & Depressive & $\begin{array}{l}\text { Kendall's } \\
\text { tau B }\end{array}$ & $\begin{array}{r}0.36 \\
8\end{array}$ & 0.270 & 0.146 & $0.517 *$ & $0.497 *$ & 0.147 \\
\hline & Moods & $p$-value & $\begin{array}{r}0.08 \\
5\end{array}$ & 0.215 & 0.498 & 0.016 & 0.022 & 0.497 \\
\hline & Role Limitation & $\begin{array}{l}\text { Kendall's } \\
\text { tau B }\end{array}$ & $\begin{array}{r}0.36 \\
8\end{array}$ & 0.336 & 0.096 & 0.302 & $0.500 *$ & 0.069 \\
\hline & Role Limitation & $p$-value & $\begin{array}{r}0.09 \\
2\end{array}$ & 0.131 & 0.662 & 0.169 & 0.024 & 0.754 \\
\hline & Hoalth Iccurc & $\begin{array}{l}\text { Kendall's } \\
\text { tau B }\end{array}$ & $\begin{array}{r}0.00 \\
0\end{array}$ & 0.014 & -0.040 & 0.175 & 0.041 & -0.162 \\
\hline & Heartn issues & $p$-value & $\begin{array}{r}1.00 \\
0\end{array}$ & 0.950 & 0.853 & 0.422 & 0.852 & 0.457 \\
\hline
\end{tabular}

Note $\mathrm{n}=$ sample size; ${ }^{*} \mathrm{p}<0.05 ;{ }^{* *} \mathrm{p}<0.01 ;{ }^{* * *} \mathrm{p}<0.001$ 
Table 7

Correlations between mother and father FQOL Scale satisfaction ratings

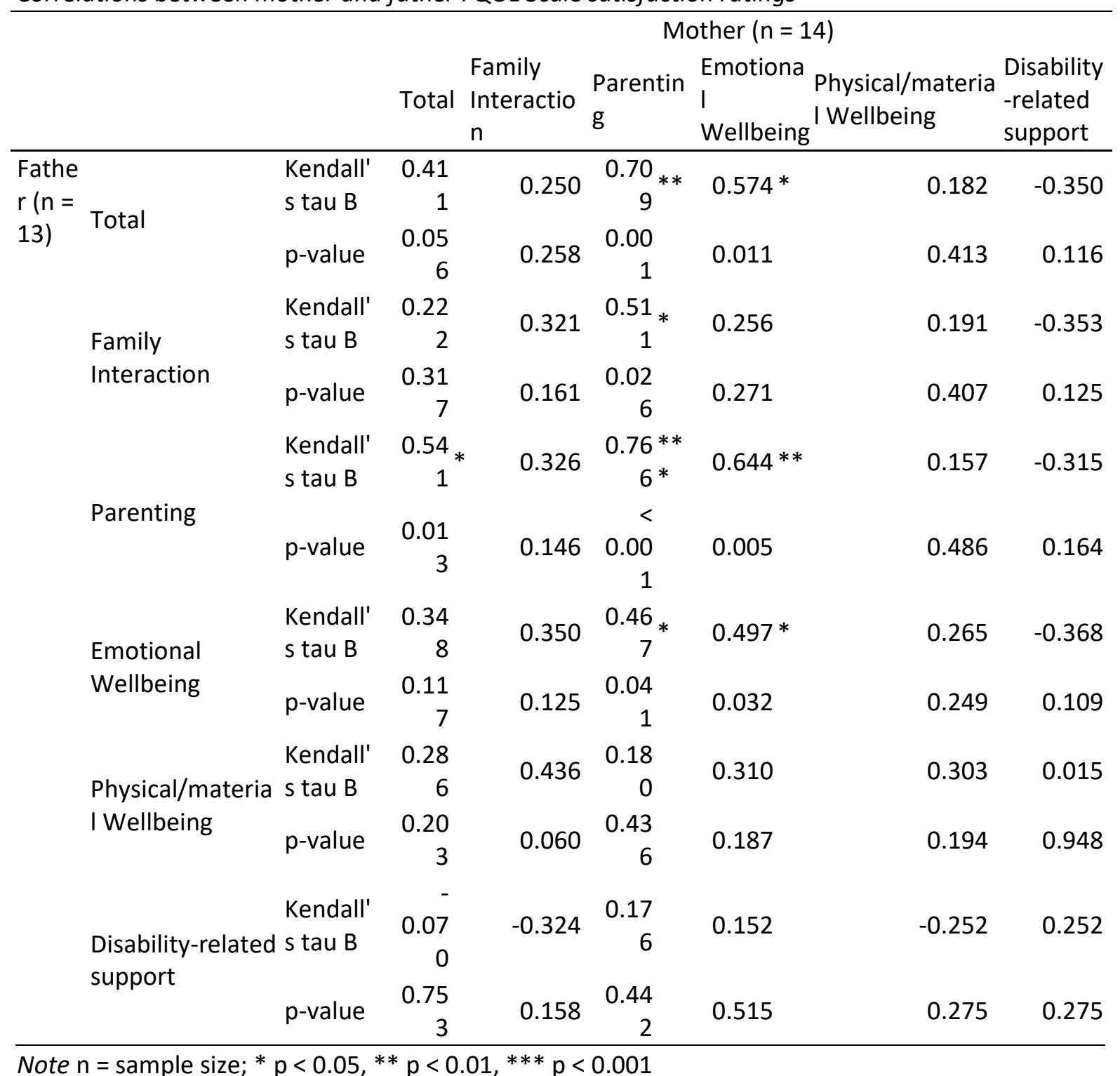

\section{Identification of potential contributing variables}

Several contributing variables in the context of parenting stress and FQOL satisfaction were explored. The individual and family characteristics displayed in Table 1 and the raw scores of the ABAS were examined for significant correlations with the PSI-SF, OBVL and FQOL scale. Because the assumptions for point-biserial correlation (the method for correlation of a binary and continuous variable) could not be met, correlations could only be calculated for the variables age, nights per week spent within the family, number of family members and the ABAS rating. Only the ABAS rating was found to be significantly related to the fathers' OBVL ( $\tau b=-0.500, p=0.020$ ) and fathers' FQOL satisfaction rating $(\tau b=0.458, p=0.032)$. No other significant relations with the PSI-SF, OBVL or FQOL scale were found. 
Next, an effect of group (divided by the individual or family characteristics above) was explored by using a Mann-Whitney U or Kruskal-Wallis test. Fathers' PSI-SF ratings differed significantly between groups of fathers that were employed $(M d n=70)$ and fathers that were not employed $(M d n=111)$ $(U=22, p=0.026)$. Also fathers' $O B V L$ ratings differed significantly between groups of fathers that were $(M d n=71)$ or were not employed $(M d n=77.5)(U=21.5, p=0.047)$. Furthermore, mothers' FQOL satisfaction ratings differed significantly between groups of mothers that had a son $(M d n=3.920)$ or mothers that had a daughter $(M d n=4.080)(U=6, p=0.047)$. No other significant group effects $(p>0.05)$ were found.

\section{Exploring the link between parenting stress and FQOL satisfaction}

Correlational analyses were performed to assess underlying relations between PSI-SF, OBVL, and FQOL satisfaction ratings. PSI-SF and OBVL ratings were significantly related (mothers $\tau b=0.469, p=0.021$; fathers $\tau b=0.562, p=0.008)$. Ratings on the FQOL scale were not significantly related to the PSI-SF (mothers $\tau b=-0.216, p=0.294$; fathers $\tau b=-0.260, p=0.221$ ), but were significantly related to the $O B V L$ (mothers $\mathrm{\tau b}=-0.655, \mathrm{p}=0.001$; fathers $\mathrm{\tau b}=-0.596, \mathrm{p}=0.006$ ). Figure 3 shows a graphical representation of the latter inverse relation.

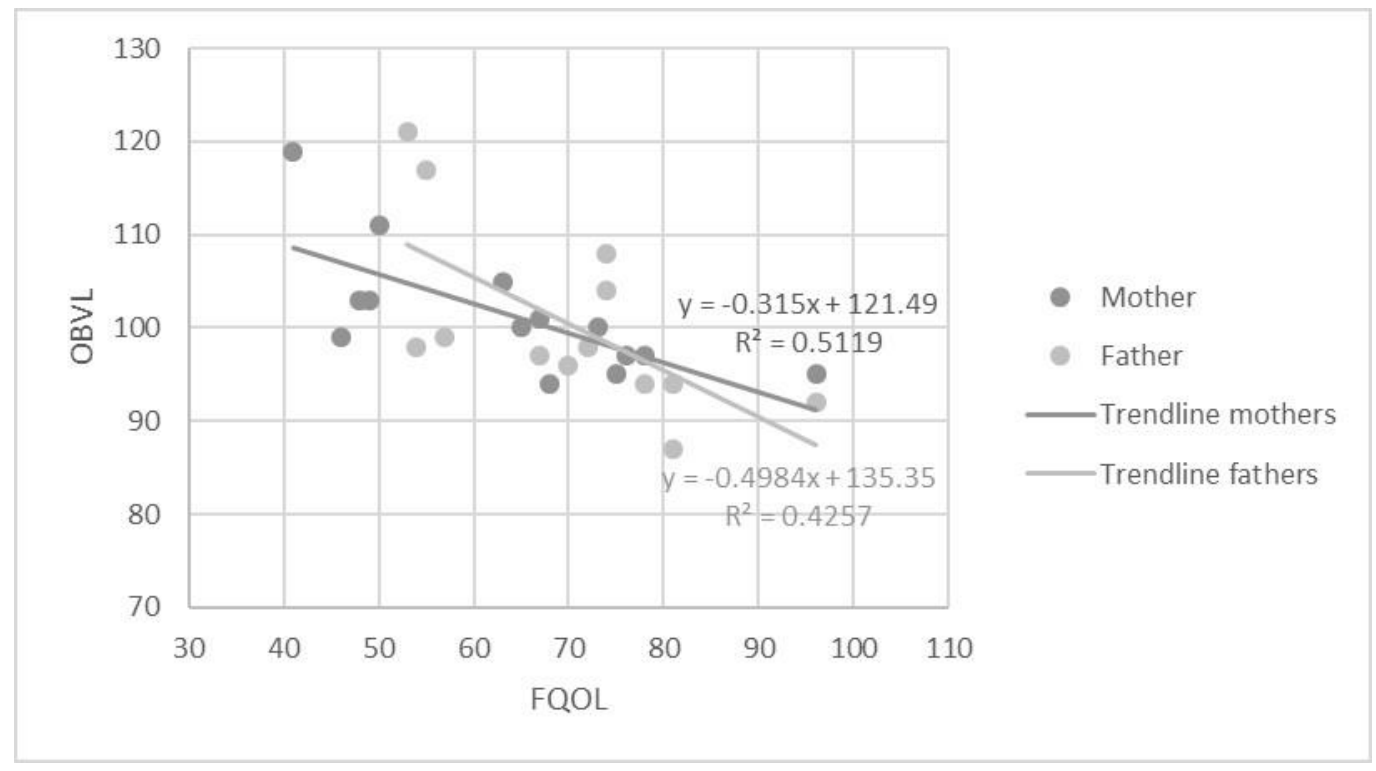

Figure 3 Inverse relation between FQOL satisfaction and OBVL ratings 


\section{Discussion}

The present study was, as far as we are aware, the first to assess parenting stress and FQOL in parents with a child with PMS. Experienced parenting stress was high for both mothers and fathers (PSI-SF mothers $M d n=86.5$, fathers $M d n=82$; OBVL mothers $M d n=68.5$, fathers $M d n=71$ ). The elevated level of parenting stress found corroborates (and elaborates) findings of studies in other clinical populations, such as mothers of individuals with Down syndrome (Phillips et al., 2017) or Fragile $X$ syndrome (Johnston et al., 2003). Notably, a very high score for the OBVL subscale Role Restriction was observed for both mothers and fathers (mothers $M d n=72.5$, fathers $M d n=77$ ). The parental role was often experienced as a restriction of one's own freedom and as a frustration resulting from repeated attempts to maintain one's own identity. This implies that, because of the demands of the child, a considerable amount of parents may feel unable to do many other things, feel like having fewer contacts and as having less "me-time" (Vermulst et al., 2015).

Despite elevated levels of parenting stress, parents were satisfied with their FQOL (mothers Mdn=4, fathers $\mathrm{Mdn}=3.92$ ). Overall, they have a sense of fulfilment of their needs as a family member. Steel et al. (2011) and Vanderkerken et al. (2018) describe similar satisfaction levels for the Flemish population. The subscale Emotional Wellbeing was rated the lowest relative to the other subscales (mothers $M d n=3.5$, fathers $M d n=3.5$ ). Half of the items of this subscale ask for the possibility of family members to pursue their own interests and the availability of contacts (e.g. friends) that provide support (Hoffman et al., 2006). The low score for emotional wellbeing seems therefore to corroborate the high score for role restriction.

The present study found no significant differences between mother and father ratings of parenting stress and FQOL satisfaction. Firstly this finding corroborates results by McCarthey et al. (2006) and by Mitchell, Szczerepa and Hauser-Cram (2016) that showed corresponding levels of parenting stress in mothers and fathers of children with Fragile X-syndrome and mothers and fathers of adolescents with intellectual disabilities, respectively. However, the corresponding parenting stress levels contradict the "stress gap" described in earlier studies by Herring et al. (2006), Oelofsen and Richardson (2006) and Shin et al. (2006). Secondly the corresponding ratings of FQOL satisfaction are analogous with findings in studies by Wang et al. (2006) and Vanderkerken et al. (2018). The overall concordance between mother and father ratings was striking: parents experienced mutually elevated levels of parenting stress, but also mutually elevated levels of FQOL satisfaction. Parents seem to function as a team: they work together and support each other regarding the upbringing of their child. This has been described in literature as supportive coparenting (McHale, 1995; Talbot, \& McHale, 2004). Supportive coparenting can alleviate the other parent's stress when she or he is overwhelmed by parenting 
demands that exceed her or his expectations or resources (Deater-Deckard, 1998; Choi, \& Becher, 2019; Holly et al., 2019; Nomagushi, \& Milkie, 2020).

Contributing variables in the context of parenting stress and FQOL satisfaction were explored for correlations with mothers' and fathers' experienced parenting stress and FQOL. No significant relations with age, nights per week spent within the family and number of family members were found. However, the adaptive skills of the individuals with PMS were found to be inversely associated with fathers' experienced parenting stress. This is in contrast to earlier findings of Lecavalier et al. (2005) with parents of children with ASD, but consistent with the study of Hassall et al. (2005) with mothers of children with intellectual disabilities. In addition, the individuals' adaptive skills were found to be positively associated with fathers' FQOL satisfaction rating. In earlier studies with children with intellectual disabilities, an inverse relationship between severity of the disability or support needs and FQOL satisfaction has also been described (Wang et al., 2004; Hu et al., 2012; Mas et al., 2016; Vanderkerken et al., 2018). In a review by Pelchat et al. (2007) various explanatory elements for the inverse association between the adaptive skills of the individual and fathers' experienced parenting stress are mentioned. For instance, fathers' experienced parenting stress is, more than with mothers, influenced by characteristics of the (health) problem of the individual. Also, it appears that fathers traditionally like to take part in playful activities with their child, but face restricted opportunities to play due to the individual's disabilities. Lastly, fathers appear to be more concerned about upholding a semblance of normality about the family (Pelchat et al., 2007). To date no studies have been conducted exploring this association with fathers' experienced FQOL satisfaction.

Experienced parenting stress was higher in fathers that were unemployed in contrast to fathers that worked full-time. Similar findings have been reported in earlier literature (Nomagushi, \& Milkie, 2020). The present study failed in finding a difference in FQOL satisfaction between employed and unemployed parents, in contrast to findings by Giné et al. (2015) and Vanderkerken et al. (2018), but consistent with Mas et al. (2016). In the general population, the material, social and psychological resources that come with employment are thought to contribute to lower levels of parenting stress (Ross, \& Mirowsky, 1995; Nomaguchi, \& Johnson, 2016; Nomaguchi, \& Milkie, 2020). Also the fulfilment of different roles (parent and employee) and the engagement in various activities can benefit the wellbeing of parents (Sieber, 1974; Vanderkerken et al., 2018).

Lastly, although both parenting stress and FQOL were rated high in general, an inverse relationship between parenting stress and FQOL was found: higher levels of parenting stress were related to lower FQOL satisfaction. This finding corroborates earlier literature on other clinical populations (Hsiao et al., 2017; Pisula, \& Porębowicz-Dörsmann, 2017; Sadhwani et al., 2019) and suggests pathways for FQOL 
satisfaction improvement through interventions aiming at decreasing the experienced parenting stress (Hsiao et al., 2017).

The present study is, to the best of our knowledge, the first to assess experienced parenting stress and FQOL in families with a child with PMS. Potentially important variables were taken into account and a link between parenting stress and FQOL was confirmed. Therefore, this study contributed to research on PMS, but possibly also to research on a broader clinical population as the present matter is not unique to a single syndrome and recommendations can be implemented in broader clinical practice. In addition to building to the existing knowledge base and informing clinical practice, the present study is characterised by two additional strong points. Firstly, both mothers and fathers were included, therefore doing justice to families' rich experiences and addressing potential bias, as mothers and fathers take different roles in the family (Perrone et al. 2005) and react in a different way on the situation of having a child with a disability (Bristol et al. 1988; Olsson and Hwang 2001; Pelchat et al. 2007). Secondly both a negative and positive measure was used for grasping the impact of having a child with a disability on a family. Following Gardiner and larocci (2012), respondents were given more opportunities to express their experiences.

Like any other study, there are a number of shortcomings. The first limitation is the small group of respondents. This requires the reader to interpret results with caution as generalizability may be limited. Moreover, the small sample size compelled the authors to restrict the amount of variables selected (such as the level of intellectual disability or the point in time the person has been diagnosed) and to limit statistical analyses to nonparametric methods, therefore losing the opportunity to perform more promising analyses. Next, only parents were included, not siblings (as did Vanderkerken et al., 2018), making it hard to make statements at a family level. Furthermore, participants' age did not always conform to the questionnaires' or norm groups' prescribed age range. Questionnaires were selected for their psychometric quality, for the comprehensive nature of the questionnaire and for the correspondence between the advised age and the developmental age of the participants. Nevertheless the non-conformity of the participants' age with the questionnaires' advised age requires the reader to interpret the results carefully. Lastly, no measure for challenging behaviour was included in the set of questionnaires. This decision was made in order to reduce the respondents' burden, but can be regarded as a shortcoming as literature does point to the role challenging behaviour plays in parenting stress or FQOL satisfaction (Lecavalier et al., 2005; Sadhwani et al., 2019).

Future research is encouraged to address and deal with these strengths and limitations in a creative way, and is recommended to explore the impact of other phenotypical traits of PMS (such as the level of intellectual disability, challenging behaviour, psychiatric disorders or medical conditions) on 
parenting stress and FQOL satisfaction as well. Regarding clinical practice the results of the present study point to the benefit of (mental) health professionals shifting their focus from merely the individual to the family system as a whole. The present study's results stress in particular the importance of parents' feelings of role restriction and the different meaning-making of fathers. The (mental) health professional is encouraged to pay attention to family dynamics and grasp opportunities to interact with these dynamics, such as proactively asking for activities undertaken for oneself (to probe for indications of parental role restriction) or recommending the use of respite care initiatives. 


\section{References}

Abidin, R. (1992). The determinants of parenting behavior. Journal of Clinical Child Psychology, 21(4), 407-412.

Abidin, R. (1995). Parenting Stress Index (3rd ed.). Odessa, FL: Psychological Assessment Recources.

Baker, B., McIntyre, L., Blacher, J., Crnic, K., Edelbrock, C., \& Low, C. (2003). Pre-school children with and without developmental delay: behaviour problems and parenting stress over time. Journal of Intellectual Disability Research, 47, 217-230. doi: 10.1046/j.13652788.2003.00484.x

Beach Center on Disability. (2003). Family quality of life conversation guide. Lawrence, KS: University of Kansas.

Beach Center on Disability (2005) Beach Center Family Quality of Life Scale User's Manual. Lawrence, KS: University of Kansas.

Bonaglia, M. C., Giorda, R., Beri, S., De Agostini, C., Novara, F., Fichera, M., Grillo, L., Galesi, O., Vetro, A., Ciccone, R., Bonati, M.T., Giglio, S., Guerrini, R., Osimani, S., Marelli, S., Zucca, C, Grasso, R., Borgatti, R., Mani, E., ..., Zuffardi, O. (2011). Molecular Mechanisms Generating and Stabilizing. PLOS Genetics, 7(7), 1-12. doi: 10.1371/journal.pgen.1002173

Bonaglia, M. C., Giorda, R., Borgatti, R., Felisari, G., Gagliardi, C., Selicorni, A., \& Zuffardi, O. (2001). Disruption of the ProSAP2 gene in a t(12;22)(q24.1; q13.3) is associated with the 22q13.3 deletion syndrome. American Journal of Human Genetics, 69(2), 261-268. doi: $10.1086 / 321293$

Bonaglia, M.C., Giorda, R., Mani, E., Aceti, G., Anderlid, B.M., Baroncini, A., Pramparo, T., \& Zuffardi, O. (2006). Identification of a recurrent breakpoint within the SHANK3 gene in the 22q13.3 deletion syndrome. Journal of Medical Genetics, 43, 822-828.

Bristol, M. M., Gallagher, J. J., \& Schopler, E. (1988). Mothers and fathers of young developmentally disabled and nondisabled boys: Adaptation and spousal support. Developmental Psychology, 24, 441-451. doi: 10.1037/0012-1649.24.3.441

Choi, J.-K. and Becher, E. H. (2019). Supportive coparenting, parenting stress, harsh parenting, and child behavior problems in nonmarital families. Family Process, 58(2): 404-417. doi: 10.1111/famp.12373

COTAN. (1996). Nijmeegse ouderlijke stress index, NOSI. Retrieved Octobre 2019, from COTAN Documentatie: https://www.cotandocumentatie.nl/beoordelingen/b/14411/nijmeegseouderlijke-stress-index/

Cusmano-Ozog, K., Manning, M., \& Hoyme, H. (2007). 22q13.3 deletion syndrome: a recognizable malformation syndrome associated with marked speech and language delay. American Journal of Medical Genetics, 145C(4), 393-398. doi: 10.1002/ajmg.c.30155

De Brock, A., Vermulst, A., Gerris, J., \& Abidin, R. (1992). NOSI Nijmeegse Ouderlijke Stress Index: Handleiding experimentele versie. Lisse, The Netherlands: Swets en Zeitlinger.

Deater-Deckard, K. (1998). Parenting stress and child adjustment: Some old hypotheses and new questions. Clinical Psychology: Science and Practice, 5, 314-332. doi: 10.1111/j.14682850.1998.tb00152.x 
Deater-Deckard, K. (2004). Parenting stress. New Haven, CT: Yale University Press.

Deater-Deckard, K., \& Scarr, S. (1996). Parenting stress among dual-earner mothers and fathers: Are there gender differences? Journal of Family Psychology, 10(1), 45-59. doi: 10.1037/08933200.10.1.45

Denayer, A., Van Esch, H., de Ravel, T., Frijns, J.-P., Van Buggenhout, G., Vogels, A., Devriendt, K., Geutjens, J., Thiry, P., \& Swillen, A. (2012). Neuropsychopathology in 7 patients with the 22q13.3 deletion syndrome: Presence of bipolar disorder and progressive loss of skills. Molecular Syndromology, 3(1), 14-20. doi: 10.1159/000339119

Dhar, S., del Gaudio, D., German, J., Peters, S., Ou, Z., Bader, P., \& Sahoo, T. (2010). 22q13.3 deletion syndrome: Clinical and molecular analysis using array CGH. American Journal of Medical Genetics, 152A(3), 573-581. doi: 10.1002/ajmg.a.33253

Droogmans, G., Swillen, A., \& Van Buggenhout, G. (2019). Deep Phenotyping of Development, Communication and Behaviour in Phelan-McDermid Syndrome. Molecular Syndromology, 10, 294-305. doi: 10.1159/000503840

Durand, C.M., Betancur, C, Boeckers, T.M.,Bockmann, J., Chaste, P., Fauchereau, F., Nygren, G., Rastam, M., Gillberg, I.C., Anckarsäter, H., Sponheim, E., Goubran-Botros, H., Delorme, R., Chabane, N., Mouren-Simeoni, M.-C., de Mas, P., Biet, E., Rogé, B., Héron, D., ..., Bourgeron, T. (2007). Mutations in the gene encoding the synaptic scaffolding protein SHANK3 are associated with autism spectrum disorders. Nature genetics, 39, 25-27. doi: 10.1038/ng1933

Egger, J., Zwanenburg, R., van Ravenswaaij-Arts, C., Kleefstra, T., \& Verhoeven, W. (2016). Neuropsychological phenotype and psychopathology in seven adult patients with PhelanMcDermid syndrome: Implications for treatment strategy. Genes, Brain and Behaviour, 15, 395-404. doi: 10.1111/gbb.12285

Gardiner, E., \& larocci, G. (2012). Unhappy (and happy) in their own way: A developmental psychopathology perspective on quality of life for families living with developmental disability with and without autism. Research in Developmental Disabilities, 33(6), 2177-2192. doi: $10.1016 /$ j.ridd.2012.06.014

Giné, C., Gràcia, M., Vilaseca, R., Beltran, F.S., Balcells-Balcells, A., Dalmau Montalà, M., AdamAlcocer, A.L., Pro, M.T., Simó-Pinatella, D., \& Mas Mestre, J.M. (2015). Family quality of life of people with intellectual disability in Catalonia. Journal of Policy and Practice in Intellectual Disabilities, 12, 244-254. doi: 10.1111/jppi.12134

Harrison, P. L., \& Oakland, T. (2015). Adaptive Behavior Assessment System, Third Edition [Manual]. Torrance, CA: Western Psychological Services.

Hassall, R., Rose, J., \& McDonald, J. (2005). Parenting stress in mothers of children with an intellectual disability: the effects of parental cognitions in relation to child characteristics and family support. Journal of Intellectual Disability Research, 49(6), 405-418. doi: 10.1111/j.1365-2788.2005.00673.x

Havens, J. M., Visootsak, J., Phelan, M. C., \& Graham, J. M. (2004). 22q13 Deletion Syndrome: An Update and Review for the Primary Pediatrician. Clinical Pediatrics, 43(1), 43-53. doi: 10.1177/000992280404300106 
Herring, S., Gray, K., Taffe, J., Tonge, B., Sweeney, D., \& Einfeld, S. (2006). Behaviour and emotional problems in toddlers with pervasive developmental disorders and developmental delay: associations with parental mental health and family functioning. Journal of Intellectual Disability Research, 50(12), 874-882. doi: 10.1111/j.1365-2788.2006.00904.x

Hoaglin, D. C., Mosteller, F., \& Tukey, J. W. (Eds.). (1983) Understanding robust and exploratory data analysis. New York: Wiley.

Hodapp, R., Dykens, E., Evans, D., \& Merighi, J. (1992). Maternal Emotional Reactions to Young Children with Different Types of Handicaps. Journal of Developmental \& Behavioral Pediatric, 13(2), 118-123.

Hoffman, L., Marquis, J., Poston, D. J., Summers, J. A., \& Turnbull, A. (2006). Assessing family outcomes: Psychometric evaluation of the beach center family quality of life scale. Journal of Marriage and Family, 68, 1069-1083. doi: 10.1111/j.1741-3737.2006.00314.x

Holly, L., Fenley, A., Kritikos, T., Merson, R., Abidin, R., \& Langer, D. (2019). Evidence-Base Update for Parenting Stress Measures in Clinical Samples. Journal of Clinical Child \& Adolescent Psychology, 48(5), 685-705. doi: 10.1080/15374416.2019.1639515

Hsiao, Y. J., Higgins, K., Pierce, T., Whitby, P. J. S., \& Tandy, R. D. (2017). Parental stress, family quality of life and family-teacher partnerships: Families of children with autism spectrum disorder. Research in Developmental Disabilities, 70, 152-162. doi: 10.1016/j.ridd.2017.08.013

Hu, X., Wang, M., \& Fei, X. (2012). Family quality of life of Chinese families of children with intellectual disabilities. Journal of Intellectual Disability Research, 56(1), 30-44. doi: 10.1111/j.1365-2788.2011.01391.x

JASP Team (2019). JASP (Version 0.11.1) [Computer software].

Johnston, C., Hessl, D., Blasey, C., Eliez, S., Erba, H., Dyer-Friedman, J., Glaser, B., \& Reiss, A.L. (2003). Factors Associated with Parenting Stress in Mothers of Children with Fragile X Syndrome. Journal of Developmental \& Behavioral Pediatrics, 24(4), 267-275. doi: 10.1097/00004703200308000-00008

Kolevzon, A., Angarita, B., Bush, L., Wang, A., Frank, Y., Yang, A., \& Buxbaum, J. (2014). PhelanMcDermid syndrome: a review of the literature and practice parameters for medical assessment and monitoring. Journal of Neurodevelopmental Disorders, 6(1, 6(1), 39.

Kreemers, B., Briers, V., Maljaars, J., Storms, G., Maes, B., \& Noens, I. (2019). De ontwikkeling van een Vlaamse schaal voor adaptief gedrag (rapport 29). Steunpunt Welzijn, Volksgezondheid en Gezin (SWVG): Leuven.

Lecavelier, L., Leone, S., \& Wiltz, J. (2005). The impact of behaviour problems on caregiver stress in young people with autism spectrum disorders. Journal of Intellectual Disability Research, 50(3), 172-183. doi: 10.1111/j.1365-2788.2005.00732.x

Luijkx, J., van der Putten, A., \& Vlaskamp, C. (2017). Time use of parents raising children with severe or profound intellectual and multiple disabilities. Child: Care, Health and Development, 43(4), 518-526. doi: 10.1111/cch.12446

Maes, B., Broekman, T., Došen, A., \& Nauts, J. (2003). Caregiving burden of families looking after persons with intellectual disability and behavioural or psychiatric problems. Journal of Intellectual Disability Research, 47(6), 447-455. doi: 10.1046/j.1365-2788.2003.00513.x 
Manning, M. A., Cassidy, S. B., Clericuzio, C., Cherry, A. M., Schwartz, S., Hudgins, L., Enns, G. M., \& Hoyme, H. E. (2004). Terminal 22q Deletion Syndrome: A Newly Recognized Cause of Speech and Language Disability in the Autism Spectrum. Pediatrics, 114(2), 451-457. doi: 10.1542/peds.114.2.451

Mas, J. M., Baqués, N., Balcells-Balcells, A., Dalmau, M., Giné, C., Gràcia, M., \& Vilaseca, R. (2016). Family quality of life for families in early intervention in Spain. Journal of Early Intervention, 38, 59-74. doi: 10.1177/1053815116636885

McHale, J. P. (1995). Coparenting and triadic interactions during infancy: The roles of marital distress and child gender. Developmental Psychology, 31(6), 985-996. doi: 10.1037/00121649.31.6.985

McCarthy, A., Cuskelly, M., van Kraayenoord, \& C.E., Cohen, J. (2006). Predictors of stress in mothers and fathers of children with fragile $\mathrm{X}$ syndrome. Research in Developmental Disabilities, 27(6), 688-704. doi: 10.1016/j.ridd.2005.10.002

Mitchell, D.B., Szczerepa, A., Hauser-Cram, P. (2016). Spilling over: Partner parenting stress as a predictor of family cohesion in parents of adolescents with developmental disabilities. Research in Developmental Disabilities, 49-50, 258-267. doi: 10.1016/j.ridd.2015.12.007

Nomaguchi, K., \& Johnson, W. (2016). Parenting stress among low-income and working-class fathers: The role of employment. Journal of Family Issues, 37(11), 1535-1557. doi: $10.1177 / 0192513 \times 14560642$

Nomaguchi, K. and Milkie, M.A. (2020). Parenthood and well-being: A decade in review. Journal of Marriage and Family, 82(1): 198-223. doi: 10.1111/jomf.12646

Oelofsen, N., \& Richardson, P. (2006) Sense of coherence and parenting stress in mothers and fathers of preschool children with developmental disability. Journal of Intellectual and Developmental Disability, 31:1, 1-12, doi: 10.1080/13668250500349367

Olsson, M. B., \& Hwang, C. P. (2001). Depression in mothers and fathers of children with intellectual disability. Journal of Intellectual Disability Research, 45, 535-543. doi: 10.1046/j.13652788.2001.00372.x

Park, J., Hoffman, L., Marquis, J., Turnbull, A. P., Poston, D. J., Mannan, H., Wang, M, \& Nelson, L.L. (2003). Toward assessing family outcomes of service delivery: Validation of a family quality of life survey. Journal of Intellectual Disability Research, 47, 367-384. doi: 10.1046/j.13652788.2003.00497.x

Pelchat, D., Lefebvre, H., \& Levert, M. J. (2007). Gender differences and similarities in the experience of parenting a child with a health problem: Current state of knowledge. Journal of Child Health Care, 11, 112-131. doi: 10.1177/1367493507076064

Perrone, K. M., Webb, L. K., \& Blalock, R. H. (2005). The effects of role congruence and role conflict on work, marital, and life satisfaction. Journal of Career Development, 31, 225-238. doi: $10.1007 /$ s10871-005-4737-9

Phelan, K., \& McDermid, H. (2012). The 22q13.3 Deletion Syndrome (Phelan-McDermid Syndrome). Molecular Syndromology, 2(3-5), 186-201. doi: 10.1159/000334260

Phelan, M. C., Rogers, C. R., Saul, R. A., Stapleton, G. A., Sweet, K., McDermid, H., Shaw, S.R., Claytor, J., Willis, J., \& Kelly, D.P. (2001). 22q13 deletion syndrome. American Journal of Medical 
Genetics, 101(2), 91-99. doi: 10.1002/1096-8628(20010615)101:2<91::AIDAJMG1340>3.0.CO;2-C

Phelan-McDermid Syndrome Foundation. (2019). What is Phelan-McDermid Syndrome? https://www.pmsf.org/about_pms/

Phillips, B., Conners, F., \& Curtner-Smith, M. (2017). Parenting children with down syndrome: An analysis of parenting styles, parenting dimensions, and parental stress. Research in Developmental Disabilities, 9-19. doi: 10.1016/j.ridd.2017.06.010

Pisula, E., \& Porębowicz-Dörsmann, A. (2017). Family functioning, parenting stress and quality of life in mothers and fathers of Polish children with high functioning autism or Asperger syndrome. PloS one, 12(10). doi:10.1371/journal.pone.0186536

Quine, L., \& Pahl, J. (1991). Stress and coping in mothers caring for a child with severe learning difficulties: A test of Lazarus' transactional model of coping. Journal of Community \& Applied Social Psychology, 1(1), 57-70. doi: 10.1002/casp.2450010109

Reierson, G., Bernstein, J., Froehlich-Santino, W., Urban, A., Purmann, C., Berquist, S., Jordan, J., O'Hara, R., \& Hallmayer, J. (2017). Characterizing regression in Pehaln McDermid Syndrome (22q13 deletion syndrome). Journal of Psychiatric Research, pp. 139-144. doi: 10.1016/j.jpsychires.2017.03.010

Rillotta, F., Kirby, N., \& Shearer, J. (2010). A comparison of two family quality of life measures: An Australian study. In R. Kober (Ed.), Enhancing the quality of life of people with intellectual disabilities: From theory to practice (pp. 305-348). London: Springer.

Ross, C. E., Mirowsky, J. (1995). Does employment affect health? Journal of Health and Social Behavior, 36, 230-243.

Sadhwani, A, Willen, J. M., LaVallee, N., Stepianis, M., Miller, H. Peters, S. U, Barbieri-Welge, R. L., Horowitz, L. T., Noll, L. M., Hundley, R. J., Bird, L. M., \& Tan, W.-H. (2019). Maladaptive behaviors in individuals with Angelman syndrome. American Journal of Medical Genetics Part A, 179(6), 983-992. doi: 10.1002/ajmg.a.61140

Sarasua, S.M., Boccuto, L., Sharp, J.L., Dwivedi, A., Chen, C.F., Rollins, J.D., Rogers, R.C., Phelan, K., \& DuPont, B.R. (2014). Clinical and genomic evaluation of 201 patients with Phelan-McDermid syndrome. Human Genetics, 133, 847-859.

Schalock, R. L. (2004). Adaptive behavior: Its conceptualisation and measurement. In E. Emerson, C. Hatton, T. Thompson \& T.R. Parmenter (Eds.), The international handbook of applied research in intellectual disabilities (pp. 369-384). Chichester, UK: John Wiley \& Sons, Ltd.

Schalock, R. L., \& Luckasson, R. (2004). The renaming of mental retardation: Understanding the change to the term intellectual disability. Journal of Intellectual and Developmental Disabilities, 45, 116- 124.

Serret, S., Thummler, S., Dor, E., Vesperini, S., Santos, A., \& Askenazy, F. (2015). Lithium as a rescue therapy for regression and catatonia features in two SHANK3 patients with autism spectrum disorder: case reports. BMC Psychiatry, 15(1), 1-6. doi: 10.1186/s12888-015-0490-1

Shaw, S. R., Rahman, A., \& Sharma, A. (2011). Behavioral profiles in Phelan-McDermid syndrome: Focus on mental health. Journal of Mental Health Research in Intellectual Disabilities, 4(1), 118. doi: 10.1080/19315864.2011.554615 
Shin, J., Nhan, N.V., Crittenden, K.S., Hong, H.T.D., Flory, M., \& Ladinsky, J. (2006). Parenting stress of mothers and fathers of young children with cognitive delays in Vietnam. Journal of Intellectual Disability Research, 50: 748-760. doi: 10.1111/j.1365-2788.2006.00840.x

Sieber, S. D. (1974). Toward a theory of role accumulation. American Sociological Review, 39, 567578. doi: $10.2307 / 2094422$

Soorya, L., Kolevzon, A., Zweifach, J., Lim, T., Dobry, Y., Schwartz, L., Frank, Y., Wang, A.T., Cai, G., Parkhomenko, E., Halpern, D., Grodberg, D., Angarita, B., Willner, J.P., Yang, A., Canitano, R., Chaplin, W,. Betancur, C., \& Buxbaum, J.D. (2013). Prospective investigation of autism and genotype-phenotype correlations in 22q13 deletion syndrome and SHANK3 deficiency. Molecular Autism, 4(18), p. 1. doi: 10.1186/2040-2392-4-18

Steel, R., Poppe, L., Vandevelde, S., Van Hove, G. and Claes, C. (2011). Family quality of life in 25 Belgian families: Quantitative and qualitative exploration of social and professional support domains. Journal of Intellectual Disability Research, 55: 1123-1135. doi:10.1111/j.13652788.2011.01433.x

Summers, J.A., Poston, D.J., Turnbull, A.P., Marquis, J., Hoffman, L., Mannan, H. and Wang, M. (2005), Conceptualizing and measuring family quality of life. Journal of Intellectual Disability Research, 49: 777-783. doi: 10.1111/j.1365-2788.2005.00751.x

Talbot, J. A., \& McHale, J. P. (2004). Individual parental adjustment moderates the relationship between marital and coparenting quality. Journal of adult development, 11(3), 191-205. doi:10.1023/B:JADE.0000035627.26870.f8

Vanderkerken, L., Heyvaert, M., Onghena, P., \& Maes, B. (2018) Quality of life in Flemish families with a child with an intellectual disability: a multilevel study on opinions of family members and the impact of family member and family characteristics. Applied Research in Quality Life, 13 (3), 779-802. doi: 10.1007/s11482-017-9558-z

Vermulst, A., Kroes, G., De Meyer, R., Nguyen, L., \& Veerman, J. (2015). Handleiding OBVL. Nijmegen, The Netherlands: Praktikon.

Wang, M., Turnbull, A. P., Summers, J. A., Little, T. D., Poston, D. J., Mannan, H., \& Turnbull, H. R. (2004). Severity of disability and income as predictors of parents' satisfaction with their family quality of life during early childhood years. Research \& Practice for Persons with Severe Disabilities, 29(2), 82-94.

Wang, M., Summers, J.A., Little, T. D., Turnbull, A. P., Poston, D. J. and Mannan, H. (2006), Perspectives of fathers and mothers of children in early intervention programmes in assessing family quality of life. Journal of Intellectual Disability Research, 50: 977-988. doi:10.1111/j.1365-2788.2006.00932.x

Zuna, N., Summers, J. A., Turnbull, A. P., Hu, X., \& Xu, S. (2010). Theorizing about family quality of live. In R. Kober (Ed.), Enhancing the quality of life of people with intellectual disabilities: From theory to practice (pp. 241-278). London: Springer.

Zwanenburg, R. J., Ruiter, S. A. J., van den Heuvel, E. R., Flapper, B. C. T., \& Van Ravenswaaij-Arts, C. M. A. (2016). Developmental phenotype in Phelan-McDermid (22q13.3 deletion) syndrome: A systematic and prospective study in 34 children. Journal of Neurodevelopmental Disorders, 8(16), 1-12. doi: 10.1186/s11689-016-9150-0 